inexpensive tool to combat diseases that disproportionately affect underserved populations in the country may be irretrievably lost.

Acknowledgments. I thank Dr Glenn Branch, Deputy Director National Center for Science Education (NCSE), Oakland, California, who kindly assisted me in producing this text with a review of the English.

Financial support. No financial support was provided relevant to this article.

Conflicts of interest. The author reports no conflicts of interest relevant to this article.

\section{References}

1. Silva HM. Medicines and illusions in the fight against COVID-19 in Brazil. Ethics Med Public Health 2021;16:100622.

2. Orso D, Federici N, Copetti R, Vetrugno L, Bove T. Infodemic and the spread of fake news in the COVID-19-era. Eur J Emerg Med 2020;27:327-328.

3. Islam MS, Sarkar T, Khan SH, et al. COVID-19-related infodemic and its impact on public health: a global social media analysis. Am J Trop Med Hyg 2020;10:1621-1629.
4. Fleming A. Penicillin. Br Med J 1941;2:386.

5. Echeverría-Esnal D, Martin-Ontiyuelo C, Navarrete-Rouco ME, et al. Azithromycin in the treatment of COVID-19: a review. Expert Rev Anti Infect Ther 2021;19:147-163.

6. Furtado RHM, Berwanger O, Fonseca HA, et al. Azithromycin in addition to standard of care versus standard of care alone in the treatment of patients admitted to the hospital with severe COVID-19 in Brazil (COALITION II): a randomised clinical trial. Lancet 2020;396:959-967.

7. Alizargar J. Dangers of the use of hydroxychloroquine and azithromycin combination in COVID-19 patients. Travel Med Infect Dis 2020;38:101881.

8. Peters DH, Friedel HA, McTavish D. Azithromycin. Drugs 1992;44: 750-799.

9. Oldenburg CE, Doan T. Azithromycin for severe COVID-19. Lancet 2020;396:936-937.

10. Venditto VJ, Haydar D, Abdel-Latif A, et al. Immunomodulatory effects of azithromycin revisited: potential applications to COVID-19. Front Immunol 2021;12:285.

\title{
The quiet before the storm: Negligence and inappropriateness in face mask use in the community preceded devastating second wave of coronavirus disease 2019 (COVID-19) in Brazil
}

\author{
Nicole de Micy Ferreira Cintra MS, Thales Cabral Benini Felisberto MS, Ingrid Costa Limeira MS, \\ Moriê Letícia Dalera de Carli MS, Thamyres Siqueira Cruz MS, Gabriel Manha dos Santos MS, \\ Laura de Camargo Vaz MS, Lucas Andrade Toledo MS, Cristiane Ravagnani Fortaleza RN, \\ Lenice do Rosário de Souza MD, PhD and Carlos Magno Castelo Branco Fortaleza MD, PhD (1) \\ Department of Infectious Diseases, Botucatu Medical School, Universidade Estadual Paulista (UNESP), City of Botucatu, State, Brazil
}

To the Editor-As of June 2021, Brazil has approached 500,000 deaths from coronavirus disease 2019 (COVID-19, https://covid. saude.gov.br/). Hundreds of patients die every day while awaiting intensive care unit beds. Hospitals face shortages of hypnotic drugs and muscle relaxants for patients requiring mechanical ventilation. ${ }^{1}$ The Brazilian president's denialism, ${ }^{2}$ lack of vaccines, ${ }^{3}$ and lack of coherent social distancing policies ${ }^{3}$ have undermined COVID-19 control. We hypothesize that, both as an additional factor and as consequence of the previously cited failures, population negligence in using face masks was one of the triggers of the devastating second wave that threatens Brazil since January 2021.

We conducted a cross-sectional study to analyze predictors of no use of masks or incorrect mask use (masks not covering nose or mouth) in the commercial center of Botucatu, a city with 150,000 inhabitants located in inner São Paulo State, Brazil. This city is the central hub of a regional health division and is home to a Public Medical School and a teaching hospital. It has been severely threatened by COVID-19 since April 2020. After a peak

Author for correspondence: Carlos Magno Castelo Branco Fortaleza, E-mail: carlos. fortaleza@unesp.br

Cite this article: Cintra N, et al. (2022). The quiet before the storm: Negligence and inappropriateness in face mask use in the community preceded devastating second wave of coronavirus disease 2019 (COVID-19) in Brazil. Infection Control \& Hospital Epidemiology, 43: 1993-1995, https://doi.org/10.1017/ice.2021.395 of cases in July 2020, a gradual decrease in that number occurred until November, when case numbers started to increase again. ${ }^{5}$

Our study was conducted from September 21 through 27. During that period, the so-called "São Paulo Plan" (https://www. saopaulo.sp.gov.br/planosp/), which provided for the calibration of mobility restrictions according to COVID-19 epidemiological indicators, was in a phase of partial relaxation. However, a governmental decree mandated the use of face masks in public places and required retail stores to restrict entry to $25 \%$ of their usual costumers. Therefore, crowding on the sidewalks was common.

We estimated sample size of 767 in OpenEpi software (Emory University, Atlanta, GA), for a total population of 150,000 , unknown prevalence of not using masks, $5 \%$ precision in results, and effect design of 2 . That sample was expanded to achieve balanced distribution of observations per weekday and period.

The research team circulated through retail streets in cars with closed windows, following a constant and predetermined route, in the morning, afternoon and evening of each day of the week. These observations were conducted for the first 50 people seen in each repetition of the route. In total, 150 daily nonduplicate observations were recorded $(\mathrm{N}=1,050)$. Study participants were characterized by sex, apparent age (through concordance of 2 investigators), period, and weekday. Multivariable logistic 


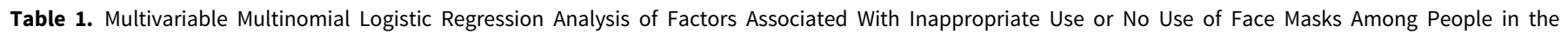
Commercial Center of Botucatu, Brazil, Between the First and Second COVID-19 Pandemic Waves

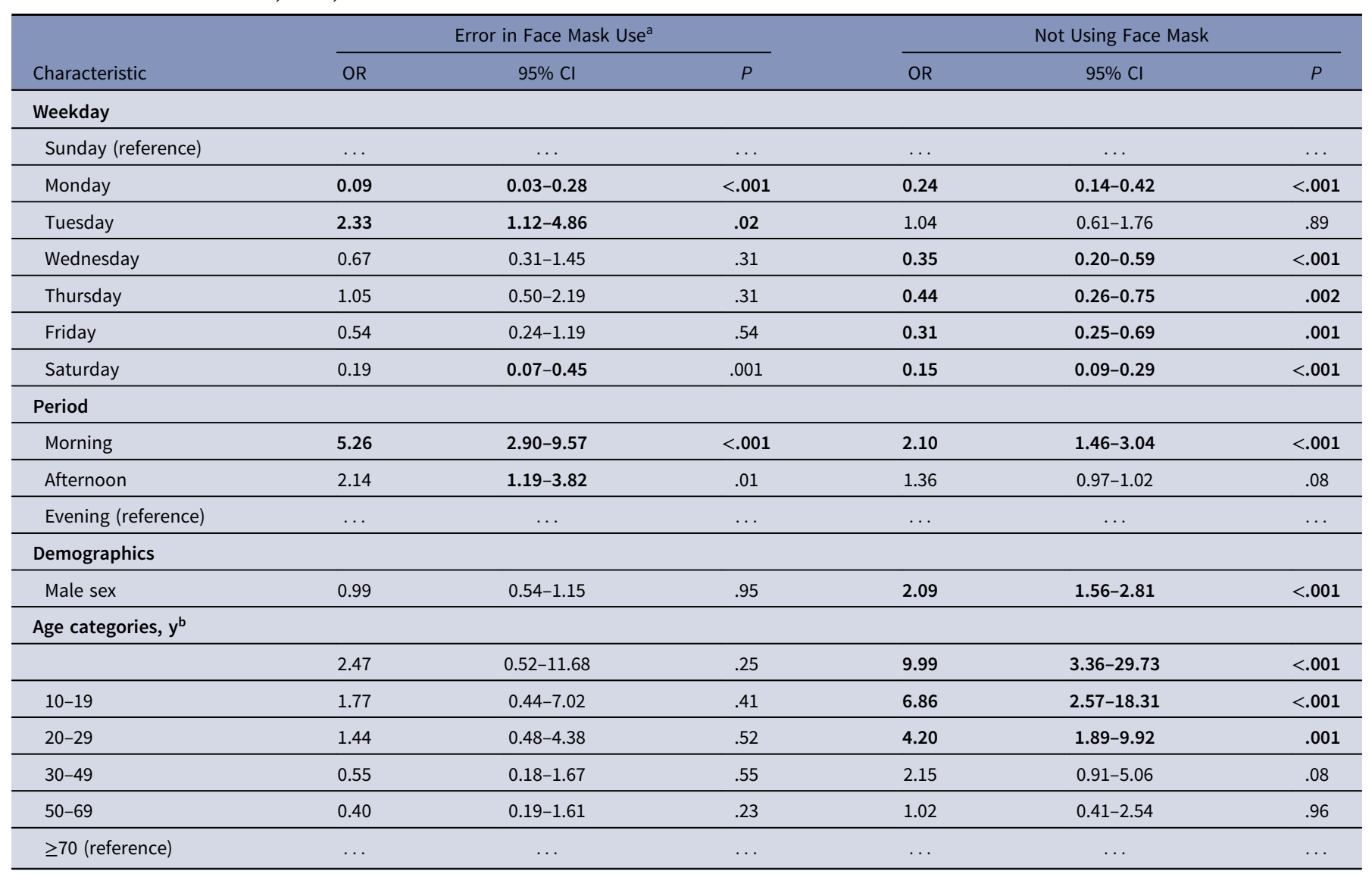

Note. OR, odds ratio; $\mathrm{Cl}$, confidence interval. Statistically significant $(P<.05)$ results are presented in boldface.

aUse of face masks not entirely covering nose or mouth.

${ }^{b}$ Apparent age was estimated by concordance of 2 members of the research team upon direct observation.

regression models with polynomial outcomes assessed independent factors associated with both inappropriate and no use of face masks using SPSS version 27 software (IBM, Armonk, NY).

Overall, $38.4 \%$ of those observed in this study did not wear masks, and $12.0 \%$ presented inappropriate use. In univariate analysis, use of face masks was significantly $(P<.05)$ associated with male sex $(44.7 \%$ vs $29.4 \%$ among women), apparent age of $<30$ years ( $44.5 \%$ vs $35.0 \%$ in older persons), Sundays, and morning periods. Except for male sex, all of the other variables were similarly associated with inappropriate use. Multivariable analysis presented similar results (Table 1).

Our findings agree with previous reports addressing self-protective behavior of general population. Male sex and younger age have been identified as predictors of not wearing face masks in publics places. ${ }^{6-9}$ That attitude has been attributed to inflated self-perception of invulnerability and COVID-19 denialism. ${ }^{7}$ It is also influenced by perceptions of overall compliance. Barile et $\mathrm{al}^{8}$ found that intention to wear face masks increased when study participants perceived that "some" or "most" others were wearing them. Also, a study conducted in the United States found that those in rural areas were less likely to wear face masks. ${ }^{9}$ This finding is relevant for our study beacuse our study was conducted in inner São Paulo State, which is relatively far from urban centers. The rural lifestyle may have affected our findings, though previous authors have reported similar results in metropolitan areas. $6,7,9$
Both our findings and those of previous studies identified a pattern of noncompliance with wearing a face mask in community settings, especially among males and those aged $<30$ years. We observed a greater likelihood of mask negligence in the mornings and on Sundays. Those findings identify targets for educational or normative interventions, which, interpreted together with results from Barile et $\mathrm{al},{ }^{8}$ may have a beneficial "herd effect." Such interventions should focus not only on the use of a mask but also on the appropriate facial coverage.

Our study was limited by the short period, the "distance observation" design, and a small sample size. Even so, it had sufficient statistical power to strengthen our hypotheses. How do these factors affect infection control and healthcare epidemiology? COVID-19 is a clear example of a disease that can be introduced into healthcare settings by patients, visitors, and healthcare workers (HCWs), causing devastating outbreaks. Overall compliance with self-protective measures in the community decreases the risk of nosocomial transmission of SARS-CoV-2. Noncompliance with face mask policies and other personal protective devices by HCWs has a harmful influence on the overall population. ${ }^{10}$ Thus, campaign to improve adherence to good practice guidelines within healthcare settings might improve adherence to self-protective behavior in community settings. Finally, in the hiatus between 2 successive epidemic waves, hospital admissions declined. This factor may have induced a false sense of security and relaxation in the use of masks. This trend 
demonstrates that risk communication, through surveillance indicators and hospital occupancy, must be done with caution. Furthermore, low adherence to social restriction and the use of masks during this "quiet" period likely contributed to the arrival of subsequent pandemic waves.

\section{Acknowledgments.}

Financial support. No financial support was provided relevant to this article.

Conflicts of interest. All authors report no conflicts of interest relevant to this article.

\section{References}

1. Alves L. Brazilian ICUs short of drugs and beds amid COVID-19 surge. Lancet 397:1431-1432.

2. COVID-19 in Brazil: "So what?" Lancet 2020;395:1461.

3. Ensuring equitable access to COVID-19 vaccines. Bull World Health Organ 2020;98:826-827.
4. Boschiero MN, Palamim CVC, Ortega MM, Mauch RM, Marson FAL. One year of coronavirus disease 2019 (COVID-19) in Brazil: a political and social overview. Ann Glob Health 2021;87:44.

5. de Almeida GB, Pronunciate M, Grotto RMT, et al. Two hundred days of COVID-19 in São Paulo State, Brazil. Epidemiol Infect 2020;148:e295.

6. Ganczak M, Pasek O, Duda-Duma $€$, Świstara D, Korzeń M. Use of masks in public places in Poland during SARS-Cov-2 epidemic: a covert observational study. BMC Public Health 2021;21:393.

7. Mahalik JR, Bianca MD, Harris MP. Men's attitudes toward mask wearing during COVID-19: understanding the complexities of mask-ulinity. J Health Psychol 2021. doi: 10.1177/1359105321990793.

8. Barile JP, Guerin RJ, Fisher KA, et al. Theory-based behavioral predictors of self-reported use of face coverings in public settings during the COVID-19 pandemic in the United States. Ann Behav Med 2021;55:82-88.

9. Haischer MH, Beilfuss R, Hart MR, et al. Who is wearing a mask? Gender-, age-, and location-related differences during the COVID-19 pandemic. PLoS One 2020;15:e0240785.

10. Picard J, Cornec G, Baron R, Saliou P. Wearing of face masks by healthcare workers during COVID-19 lockdown: what did the public observe through the French media? J Hosp Infect 2020;106:617-620.

\title{
The (in)competence of the Bolsonaro government in confronting coronavirus disease 2019 (COVID-19)
}

\author{
Heslley Machado Silva PhD \\ University Center of Formiga (UNIFOR/MG), Formiga city, and State University of Minas Gerais (UEMG), Ibirité, Brazil
}

To the Editor-When one speaks of the inability of the Brazilian government to combat the pandemic, it is generally associated with a total lack of direction and erratic policy decisions, ${ }^{1}$ but it is rarely considered that a determined path within a perverse logic is actually being followed. The use of social networks, ${ }^{2}$ some television channels, and their daily discourse follow what the Bolsonaro himself defined in April 2020: "May social isolation end, (that) life return to normal and die as many as have to die."

That is exactly what is happening in Brazil. The idea that the best vaccine would be the virus is based on the odd and perverse reasoning of Bolsonaro, which has been in practice since the beginning of the pandemic and became even more evident in March 2021. The government exhorted the Brazilians to go out and face the virus because they would be cowards if they did not. The spread of speeches in favor of drugs without scientific proof has been part of this ongoing planning. ${ }^{3}$ Misinformation (ie, "fake news") has caused more Brazilians to expose themselves and die in the belief that there is efficient treatment for COVID-19 with the support of a few thousand doctors ${ }^{4}$ and millions of followers. But as Bolsonaro said, "So what?"

These representatives continue to make daily pronouncements and postings doubting the benefits of vaccines ${ }^{6}$ because they can alter the DNA of people, they should not be mandatory, or they are experimental and were produced in a hurry. Some doctors endorse this sanctimonious fascist propaganda, and the result of this kind of

\footnotetext{
Author for correspondence: Dr. Heslley Machado Silva, E-mail: heslley@uniformg. edu.br

Cite this article: Silva HM. (2022). The (in)competence of the Bolsonaro government in confronting coronavirus disease 2019 (COVID-19). Infection Control \& Hospital Epidemiology, 43: 1995, https://doi.org/10.1017/ice.2021.431
}

ideology is evident in the deaths of the weak by suffocation shown in the images of Manaus, capital of the State of Amazonas-analogous to "gas chambers" for those who do not have the presidential "athleticism." Brazilian society must react so that this plan does not perpetuate and to save many Brazilians from this supremacist project.

\section{Acknowledgments.}

Financial support. No financial support was provided relevant to this article.

Conflicts of interest. All authors report no conflicts of interest relevant to this article.

\section{References}

1. Barberia LG, Gómez EJ. Political and institutional perils of Brazil's COVID-19 crisis. Lancet 2020;396:367-368.

2. Ricard J, Medeiros J. Using misinformation as a political weapon: COVID-19 and Bolsonaro in Brazil. Harvard Kennedy Sch Misinformation Rev 2020. doi: 10.37016/mr-2020-013.

3. Pontalti Monari AC, Santos A, Sacramento I. COVID-19 and (hydroxy) chloroquine: a dispute over scientific truth during Bolsonaro's weekly Facebook live streams. J Sci Commun 2020;19(7):A03.

4. Silva HM. Medicines and illusions in the fight against COVID-19 in Brazil. Ethics Med Public Heal 2021;16:100622.

5. COVID-19 in Brazil: "So what?" Lancet 2020;395:1461.

6. Silva HM. The danger of denialism: lessons from the Brazilian pandemic. Bull Natl Res Cent 2021;45:55. 